\title{
キウイフルーツの消化促進効果に関する研究動向 一アクチニジンの役割—
}

西山一朗

駒沢女子大学人間健康学部健康栄養学科

貯蔵性に優れ，いつでも手軽に食べられるキウイフルーツは, 日本を含め世界中で食されている。ビタミンC, カロテノイドの一種 ルテインなどを含んでおり, 食物繊維も豊富な機能性の高い食品である。さらに, キウイフルーツ果実には「アクチニジン」という特 徵的な成分が含まれている。アクチニジンはキウイフルーツから見出されたたんぱく質分解酵素で, 近年, その消化促進作用が注目さ れている。

本稿では, アクチニジンの酵素学的な特性を概説するとともに, in vitro および in vivo におけるアクチニジンの消化促進効果を検 証した最新の研究結果を紹介する。これらの研究結果から, アクチニジンは消化管で様々な食物由来たんぱく質の消化を促進し, 胃の 内容物排出速度を速めることで, アミノ酸吸収の効率を高める可能性が示唆された。高い栄養価に加え, 消化促進効果が期待できるキ ウイフルーツは, 健康の維持増進に有用な果実の一つと考えられる。

栄養学䧱誌, Vol.72 No.6 292-301 (2014)

キーワード：キウイフルーツ, アクチニジン，消化促進，たんぱく質分解酵素，健康増進

\section{I . はじめに}

\section{1. キウイフルーツの来歴と分類}

キウイフルーツは, マタタビ, サルナシ，シマサルナ シなどとともにマタタビ属 (Actinidia 属) に分類される 落葉果樹である。これらの中でキウイフルーツは，唯一 本格的な経済栽培が行われ世界中で市販されているが, その栽培の歴史は浅い。1904年, 中国の山野に自生する キウイフルーツの野生種がニュージーランドの旅行者に よって母国に持ち込まれ1)，作物化されたのがその始ま りである。その後数十年を経てニュージーランド国内で 本格的な経済栽培が開始され，1960年代になって初めて 世界の市場に姿を見せるようになった。その後わずか 30 年ほどの間にキウイフルーツ産業は急速に発展し, イ夕 リア，中国，ニュージーランド，チリ，フランス，ギリ シア, 日本, アメリカなど様々な国で栽培されるように なった2)。このような急速な市場の発展は他の作物では 類がなく，「キウイフルーツの奇跡」と呼ばれている。

今日，世界に流通しているキウイフルーツは，おもに Actinidia deliciosa（ニュージーランド系キウイフルーツ） と Actinidia chinensis（中国系キウイフルーツ）の 2 種に 分類される。キウイフルーツの中で最も広く栽培され, 一般に市販されているのが A. deliciosa に属する「へイ ワード」という品種である。へイワードは, 茶色の粗毛 に覆われた外観と, これとは対照的な明るいエメラルド
グリーンの果肉が特徵で, 適度に熟した果実は糖と酸の バランスが程よく，食味良好であり，香りも良い。ま た，非常に長期間の保存が可能であるため，収穫後半年 近く貯蔵することができ，産地から遠く離れた市場に船 で運ぶことも可能である。これらの優位性により，キウ イフルーツ市場のほとんどがへイワードによって独占さ れる時代が続いた。そのため, 最近までキウイフルーツ といえばこのへイワードのことを指し，「キウイフルーツ の果肉は緑色」というイメージが定着していた。

しかし，A. chinensisに属する「ホート16A」という明 るい黄色果肉をもつ品種がニュージーランドで開発さ れ，2000年に世界市場に登場すると，それまでのイメー ジが一変した。その後, ホート16A の生産量は急激に拡 大し, ニュージーランドのキウイフルーツ輸出量の17～ 18\%を占めるまでになっている2)。

A. deliciosa や A. chinensis のほかに，最近ではキウイ フルーツと近縁のサルナシ (A. arguta) の果実も市販さ れている。サルナシ果実はブドウのように小粒で, キウ イフルーツのような毛茸（もうじ）がないため,「ベビー キウイ」などの名前で販売されているが，その市場規模 はキウイフルーツに比べるとはるかに小さい。

2. キゥイフルーツ果実の栄養

古代中国では，キウイフルーツ果実は胃腸障害やリウ マチ, 痔など様々な疾患の症状を軽減させるための薬と して用いられており ${ }^{3)}$, 健康の維持や回復に有用である

連絡先：西山一朗 $\overline{7} 206-8511$ 東京都稲城市坂浜238 駒沢女子大学人間健康学部健康栄養学科 電話 042-350-7178 FAX 042-331-1919 E-mail inishiya@komajo.ac.jp 
表 1 キウイフルーツ果実の各種成分濃度とプロテアーゼ活性

\begin{tabular}{|c|c|c|c|}
\hline & ヘイワード & ホート16A & 文献番号 \\
\hline $\begin{array}{l}\text { ビタミン C } \\
(\mathrm{mg} / 100 \mathrm{~g})\end{array}$ & $65.5 \pm 14.2$ & $103.7 \pm 13.1$ & 6 \\
\hline $\begin{array}{l}\text { ルテイン } \\
(\mu \mathrm{g} / 100 \mathrm{~g})\end{array}$ & $418 \pm 82$ & $155 \pm 30$ & 7 \\
\hline $\begin{array}{l}\text { アクチニジン濃度 } \\
(\mathrm{mg} / \mathrm{m} l)\end{array}$ & $2.91 \pm 0.18$ & 検出限界以下 & 27 \\
\hline $\begin{array}{l}\text { プロテアーゼ活性 }^{\dagger} \\
(\mathrm{nmol} \mathrm{pNA} \text { released/min) }\end{array}$ & $6.34 \pm 0.78$ & $0.42 \pm 0.02$ & 27 \\
\hline
\end{tabular}

ことが古くから知られている。キウイフルーツに含まれ る栄養素は, ビタミン $\mathrm{C}$, ビタミン $\mathrm{E}$, 葉酸, カロテノ イド, 食物䋊維など様々である。特にビタミン C の含有 量は高く,「日本食品標準成分表2010」によると, へイ ワードのビタミン C 含有量は可食部 $100 \mathrm{~g}$ あたり $69 \mathrm{mg}$ である ${ }^{4)}$ 。日本人の食事摂取基準 $(2015 \text { 年版 })^{5)}$ では, 成 人のビタミン $\mathrm{C}$ 摂取量の推奨量は $100 \mathrm{mg} /$ 日とされて おり, 平均的な大きさのへイワードを 1 日に 1 個食べれ ば，推奨量の約70\%を補うことができる計算となる。こ のビタミン C 含有量には品種ごとに差異が認められ, ホート $16 \mathrm{~A}$ 果実のビタミン C 含有量はへイワードの約 1. 5倍に及ぶ6) (表 1 )。

また， キウイフルーツは抗酸化作用をもつカロテノイ ドの一種であるルテインの含有量も高く, ヘイワードの ルテイン濃度は可食部 $100 \mathrm{~g}$ あたり約 $420 \mu \mathrm{g}$ である7) (表 1 )。これは, 一般的に食されている果物のうち, ル テイン含有量が比較的高いリンゴ $(84 \mu \mathrm{g} /$ 可食部 100 $\mathrm{g})^{8)}$ やモモ $(78 \mu \mathrm{g} / \text { 可食部 } 100 \mathrm{~g})^{8)}$, マンダリンオレン ジ $(113 \mu \mathrm{g} / \text { 可食部 } 100 \mathrm{~g})^{9)}$ などと比べても数段高い数 值である。

キウイフルーツは食物繊維も豊富であり, 排便を促す 効果があることが知られている。Rush ら ${ }^{10)}$ は, ヘイ ワード種果実を 3 週間継続して食べることで高齢者の排 便の回数や量が増加し, 腸の動きが改善されることを報 告している。慢性的な便秘症の患者 ${ }^{11)}$ や過敏性腸症候群 の患者 ${ }^{12)}$ でも, キウイフルーツの摂取によって排便が促 され，腸の機能が改善することが示されている。

上記のように，その機能が明確な栄養成分以外に，キ ウイフルーツにはアクチニジンと呼ばれるたんぱく質分 解酵素が豊富に含まれている。アクチニジンに関して は, 従来から食肉軟化剂としての利用価值が注目を集め ていたが, その栄養生理学的な機能についてはほとんど 研究がなされていなかった。しかし，最近になってアク
チニジンの消化促進作用に関する in vitro ${ }^{13,14)}$ ならびに in vivo ${ }^{15,16)}$ での研究結果が複数報告され, その機能性が 示唆されている。本稿では, これまであまり注目される ことのなかったアクチニジンの機能性に焦点を当て, そ の酵素学的な特性や消化促進効果を紹介するとともに, 健康を維持・増進する上での利点について考察する。

\section{II . たんぱく質分解酵素「アクチニジン」}

\section{1. アクチニジンの酵素学的特性}

生のキウイフルーツ (ヘイワード種) の果肉をゼラチ ンゼリーやババロアなどに入れると, ゼラチンのゲル化 が妨げられて固まらなくなることはよく知られている。 これは，果肉に含まれる多量のたんぱく質分解酵素が, ゼラチンを加水分解することに起因する。このたんぱく 質分解酵素は1959年に Arcus ${ }^{17)}$ によって報告され，キウ イフルーツの属名である「Actinidia」に因んで「アクチ ニジン」と命名された。その後の様々な研究によって, アクチニジンの生化学的, 酵素学的な特徴が明らかにさ れている。

アクチニジンは, 酵素活性の発現にシステイン残基の チオール基を要するシステインプロテアーゼ（チオール プロテアーゼ）である ${ }^{18)}$ 。酵素分子は220のアミノ酸残基 からなり, 分子量は23,500である ${ }^{19)}$ 。アクチニジンの一 次構造は, パパイア未熟果に含まれるシステインプロテ アーゼであるパパインと似ており, 両者のアミノ酸配列 には45\%の相同性が認められ ${ }^{19)}$, また酵素の立体構造も 類似している ${ }^{20)}$ 。そのため, アクチニジンは, パパイ ン, ブロメライン（パインアップル果実に含まれるたん ぱく質分解酵素), ショウガプロテアーゼ, 哺乳類の細胞 内に含まれるカテプシン $\mathrm{B}, \mathrm{K}, \mathrm{L}$ などと同じく，パパ インスーパーファミリーとして分類される。アクチニジ ンの至適 $\mathrm{pH}$ は，ゼラチンや筋原線維たんぱく質などの 
食物たんぱく質を基質とした場合は $\mathrm{pH} 4$ 前後17,21)，人 工基質を用いた場合は $\mathrm{pH}$ 6前後18, 22 24) であることが確 かめられている。

2. キゥイフルーツ果実内におけるアクチニジン

キウイフルーツ果実中のアクチニジン濃度は, 果実成 長期に急速に増加する ${ }^{2)}$ 。そのため, 成長途中の果実に はアクチニジンは少量しか含まれていない。未成熟なパ パイア果実に含まれるパパインの量は，パパイアが成熟 する間に大きく減少するのに対し2), アクチニジン活性 は, 収穫後, キウイフルーツが成熟する間に $2 \sim 3$ 倍に 増大する ${ }^{25)}$ 。

アクチニジンは, キウイフルーツの外果皮や内果皮に 豊富に存在し, 果心部と表皮では明らかに少ないことが 複数の研究で示されている23,25,26)。一方, 果梗部から果 頂部にかけての垂直方向における分布については, 報告 されていない。

品種間でのたんぱく質分解酵素活性について調査した 著者ら ${ }^{27)}$ は，ホート16Aのたんぱく質分解酵素活性が, 最も一般的な経済栽培品種であるへイワードのたんぱく 質分解酵素活性の $7 \%$ 以下しかないことを明らかにした (表 1 )。これは, ホート16A に複数存在するアクチニジ ン遺伝子の多くにフレームシフト変異を引き起こす挿 入・欠損や活性部位の点変異があり, 不活性化されてい ることが原因の一つと考えられている28)。

アクチニジンは, 種々のたんぱく質を加水分解する幅 広い基質選択性をもっている。キウイフルーツ果実にお けるアクチニジンの生理的役割は未だ不明であるが, 成 熟したキウイフルーツ果実を病原菌から守る役割がある のではないかとも推測されている28)。

3. 食物中のたんぱく質に対するアクチニジンの作用 ヘイワード種キウイフルーツは果実中に多量のアクチ ニジンを含んでいるため, ゼラチンのようなアクチニジ ン感受性のたんぱく質を主成分とする食品に加える場 合, あらかじめ熱処理を施してたんぱく質分解酵素を不 活性化する必要がある。しかし， キウイフルーツを加熱 処理すると, 果肉の風味や鮮やかな緑色が失われ, ビ夕 ミン C や葉酸などの栄養素の多くが分解されてしまう。 この問題を解決するため, Funaki ら 29) はコメに含まれ るシステインプロテアーゼ阻害たんぱく質のオリザシス タチンを添加する方法を見出した。しかし，この方法は 実用化には至っておらず，むしろゲル化剂をゼラチンか ら寒天やカラギナンなどの多糖類に置き換える方法が主 流となっている。

また, アクチニジンは乳たんぱく質であるカゼインに 対しても加水分解作用を示し, 苦味ペプチドの生成など
の望ましくない反応の原因となることが知られてい る ${ }^{30)}$ 。一方, カゼインの分解は牛乳の凝固の原理にも関 係しており，アクチニジンをチーズの製造に役立てる試 みも，試験的に行われている31)。

パパインやブロメライン， ショウガプロテアーゼなど の植物由来のたんぱく質分解酵素には, 筋原線維たんぱ く質やコラーゲンを分解する効果がある。そのため, こ れらの酵素は肉を柔らかくするための下処理に用いられ ている ${ }^{32)}$ このうち, 最も広く用いられている酵素はパ パインであるが, パパインで肉を処理すると, 食肉表層 部において筋原線維たんぱく質の過度の加水分解が生 じ，形が崩れたりテクスチャの望ましくない変化が起 こったりする ${ }^{32)}$ 。著者ら ${ }^{21)}$ がアクチニジンの筋原線維た んぱく質に対する効果を調べたところ，アクチニジンは $\mathrm{pH}$ 3〜 4. 5 ではミオシン重鎖とアクチンを含むすべての 筋原線維たんぱく質を小さな断片にまで加水分解したの に対し, pH 5.5〜8ではミオシン重鎖を大きな断片に限 定的に加水分解し, アクチンはほとんど分解しないこと を見出した。これに対し，パパインやブロメラインには アクチニジンのような顕著な $\mathrm{pH}$ 依存性は認められず, 幅広い $\mathrm{pH}$ 領域で筋原線維たんぱく質を非特異的に加水 分解することが示された21)。このことから，肉を下処理 する際の酵素としてアクチニジンを用い, $\mathrm{pH}$ を適切に 調整すれば，食肉表面が柔らかくなりすぎるテクスチヤ の劣化をある程度コントロールできると考えられる。

上述の通り，アクチニジンは筋原線維たんぱく質など の食物たんぱく質を顕著に加水分解するため, キウイフ ルーツには消化促進効果があると考えられてきた。この ことが実証されれば,アクチニジンはキウイフルーツ果 実に含まれる重要な機能性成分として, 注目されるであ ろう。この点に関しては, IV 章で詳述する。

\section{III.たんぱく質の消化吸収}

前章でアクチニジンの消化促進効果について触れた が, ここで, 生体内でのたんぱく質の消化・吸収のしく みと，たんぱく質消化の意義について確認したい。

1.たんぱく質の消化・吸収のしくみ

摂取した食物成分の多くは，そのままの形では消化管 粘膜を通過できない。消化によって食物を単純な成分に まで分解することで, 生体で吸収・利用できるようにな る。経口摂取されたたんぱく質の消化は，胃で始まる。 胃に運ばれたたんぱく質は，胃酸によって三次構造が破 壊され，たんぱく質分解酵素が作用しやすい構造へと変 化する。高次構造が変化した変性たんぱく質は, 胃から 
分泌されるペプシンによってポリペプチドに分解され， 十二指腸へと送られる。そこで膵臓から分泌される膵液 と混ざり合い, 膵液中のトリプシン, キモトリプシン, エラスターゼ, カルボキシペプチダーゼなどによってさ らに分解され，オリゴペプチドおよび遊離アミノ酸とな る。生成されたオリゴペプチドは, 小腸内において刷子 縁膜上のアミノペプチダーゼやジペプチダーゼによって 膜消化を受け，アミノ酸，ジペプチドあるいはトリペプ チドまで分解される。管腔内消化ならびに膜消化によっ て生じたアミノ酸, ジペプチドおよびトリペプチドは, 小腸上皮細胞の刷子縁（微絨毛と終末網構）から吸収さ れ，アミノ酸はそのまま，またぺプチドは上皮細胞内で アミノ酸まで分解された後, 静脈を経由して肝臓へ送ら れる33) (図 1 )。

胃でたんぱく質を分解するペプシンは種々のペプチド 結合を加水分解するが, 特にチロシン, フェニルアラニ ン, ロイシンなどの疎水性アミノ酸のアミノ末端側のペ プチド結合に対する選択性が高い34)。アクチニジンもま た種々のペプチド結合を加水分解するが, 特にアルギニ ンやリシンなどの塩基性アミノ酸のカルボキシ末端側の ペプチド結合に対する選択性が高い22)。この基質選択性 の違いから, アクチニジンはペプシンが分解できないぺ プチド結合をも加水分解することができると考えられ る。また, ペプシンとアクチニジンとが協調して作用し た場合, アクチニジンの作用によって基質たんぱく質の 構造が変化を来し, ペプシンに感受性のある部位が新た に露出するため ${ }^{35)}$, ペプシンが単独で作用する場合より も, さらに加水分解が進むものと考えられる。

\section{2.たんぱく質消化の意義}

加齢に伴う筋肉量の低下は，身体機能の低下や病気に 対する感受性の増大につながるため ${ }^{36)}$, 高齢者では筋た んぱく質の合成に利用できるアミノ酸を効率よく吸収す ることが重要になってくる。食後のたんぱく質吸収は, たんぱく質の消化速度の影響を受けることが知られてい るが37)，後述するように，アクチニジンは消化管内で 様々な種類のたんぱく質の消化を促進する効果が期待で きるため, 高齢者のアミノ酸吸収の効率を向上させる上 で有益であると考えられる。

たんぱく質の消化は, 生体で吸収・利用されやすい成 分に分解するという点だけでなく, 免疫学的にも重要な 意味をもつ。食物たんぱく質のような非自己物質は, 生 体内では抗原とみなされ，血管に大量に注入すると過敏 な反応を引き起こし, 死に至る。しかし, 経口摂取した 場合はそのようなことは起こらない。これは，消化管内 の消化酵素によってたんぱく質抗原が分解され, アレル ギー反応の誘起能力が低下するためである ${ }^{38)}$ 。

消化性潰瘍や逆流性食道炎などの消化器疾患の患者で は，胃酸の分泌を抑制するプロトンポンプ阻害薬やヒス タミン $\mathrm{H}_{2}$ 受容体拮抗薬などの治療薬を服用している場 合が多い。これらの薬剤は胃内の $\mathrm{pH}$ を通常よりも高く し, 実質的に胃の消化機能を妨げる ${ }^{39)}$ 。消化器疾患の患 者 152 人を対象にしたコホート研究によると, プロトンポ ンプ阻害薬またはヒスタミン $\mathrm{H}_{2}$ 受容体拮抗薬を 3 カ月 間服用した結果，追跡患者の $25 \%$ で通常の食事に含まれ る成分に対する追加免疫または新規 $\operatorname{IgE}$ 形成が見られ た ${ }^{40)}$ このことから，胃酸分泌抑制薬が抗原たんぱく質

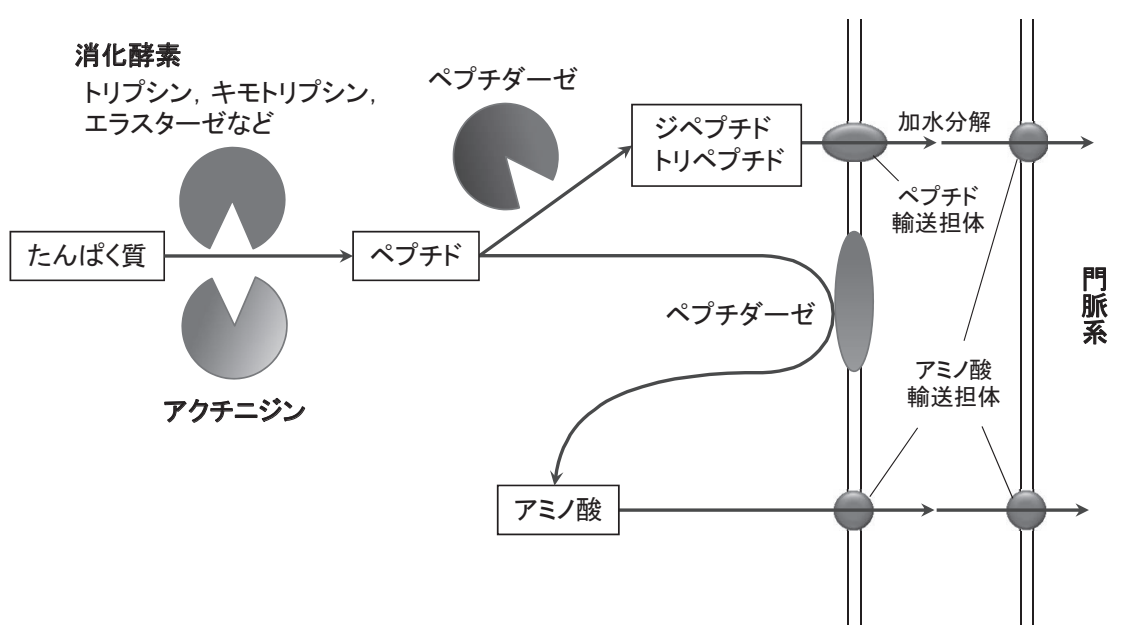

図 1 たんぱく質の消化・吸収に対するアクチニジンの関与

田平洋一: 各栄養素の消化・吸収部位と動態,「キーワードでわかる臨床栄養 改訂版」 (大熊利忠, 金谷節子編) p. 78 （2011）羊土社 より一部改変し, アクチニジンの作用ポ イントを追加した 
の消化不良を引き起こし，アレルギー反応の誘起能力を 低下させるプロセスを阻害することが示唆された。

\section{N. アクチニジンによるたんぱく質の消化促進作用}

アクチニジンは，ペプシンなどの消化酵素が単独で働 く場合と比べ，たんぱく質をより完全に，より迅速に分 解することで, 食物の消化を助けると考えられてい る14)。また, 食物中のアクチニジンが胃のたんぱく質消 化を促進することで, 胃の内容物排出速度に影響を与え る可能性が指摘されている15)。最近, これらの仮説を確 かめるための研究が, in vitro と in vivo の両方で行われ た。本章では, これらの研究結果を紹介し, そこから推 察される生体内でのアクチニジンの働きについて考察す る。

1. in vitro 消化モデルを用いた研究

ヘイワード種キウイフルーツはアクチニジンを多量に 含んでいるため, 胃での消化促進作用があると考えられ
ているが，これまで，その仮説を裏付けるエビデンスは ほとんどなかった。Kaur ら ${ }^{13)}$ は，この仮説を検証する ため, ヒトの胃内環境を模した $\mathrm{pH} 1.9$ の in vitro 消化モ デルを用い, ヘイワード種キウイフルーツ抽出物が共存 する場合としない場合とで消化の様子に違いがあるかど うかを調べた。

その結果, アクチニジンは胃の in vitro 消化モデルに おいて, カゼイン, 大豆たんぱく質, 牛肉の筋たんぱく 質の消化を促進することが示された（表 2 )。カゼインは $\mathrm{pH} 2$ の酸性条件下でペプシンによって急速に加水分解さ れることが報告されているが41), Kaur ら ${ }^{13)}$ の実験に よって, ペプシンにキウイフルーツ抽出物を共存させた 方がペプシン単独の場合よりも明らかに消化が促進され ることが示された。牛肉の筋たんぱく質でも，同様の結 果が観察された。

一方, 乳清たんぱく質, コラーゲン, ゼラチン, グル テン, グリアジンの消化に対しては, アクチニジンはほ とんど促進効果を示さなかった。乳清たんぱく質はおも

表 2 in vitro でのたんぱく質の消化に対するキウイフルーツ抽出物（アクチニジン）の効果

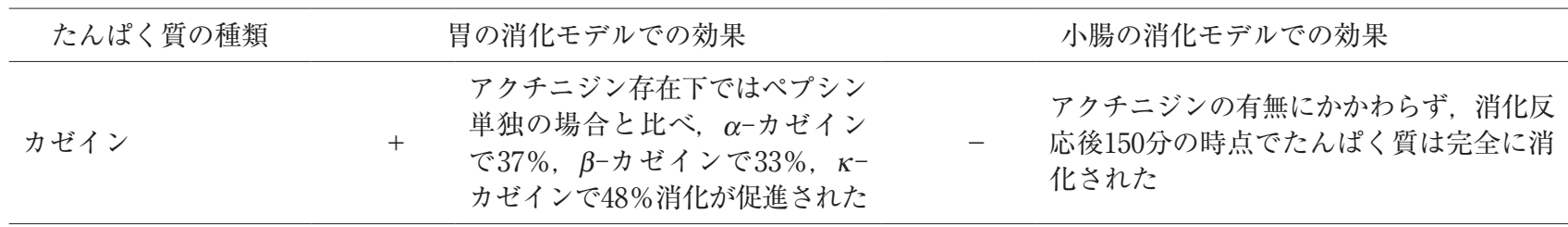

乳清たんぱく質

消化反応後150分の時点で, 未消化のまま 残存する $\beta$-ラクトグロブリンは, アクチ ニジン存在下で $59 \%$, アクチニジン非存在 下で $84 \%$ だた

消化反応後150分の時点で, 未消化のまま 残存する $\alpha$-ゼインの構成成分 Z19と Z22

ゼイン 未検出 ${ }^{\dagger}$

+ は, アクチニジン存在下でそれぞれ $61 \%$, $62 \%$, アクチニジン非存在下でそれぞれ 91\%, 93\%だった

\begin{tabular}{|c|c|c|c|}
\hline 大豆たんぱく質 & + & $\begin{array}{l}\text { いくつかのたんぱく質 }(31 \mathrm{kDa}, \\
21 \mathrm{kDa}) \text { の加水分解にわずかな効 } \\
\text { 果が見られた }\end{array}$ & $-{ }^{\ddagger}$ \\
\hline 牛肉の筋たんぱく質 & + & $\begin{array}{l}25 \mathrm{kDa} \text { 以上のすべてのたんぱく } \\
\text { 質の消化が有意に促進された }\end{array}$ & - \\
\hline コラーゲン & - & & $+\quad$ わずかに促進された \\
\hline ゼラチン & - & & 未測定 \\
\hline グルテン & - & & + \\
\hline グリアジン & - & $\begin{array}{l}\text { アクチニジン存在下で, ペプシン } \\
\text { による消化が減弱した }\end{array}$ & + \\
\hline
\end{tabular}

+ ：アクチニジンの消化促進効果あり, - : アクチニジンの消化促進効果なし

胃の in vitro 消化モデルでは30分, 小腸の in vitro 消化モデルでは 2 時間反応させた。

† たんぱく質の溶解性が低く, デー夕を検出できなかった。

‡11S グロブリンのポリペプチドは，アクチニジンの存在下で消化が促進された。

Kaur, L., et al.（13）および Kaur, L., et al.（14）より許可を得て改変し転載Ｃopyright（2010） American Chemical Society 
に $\alpha$-ラクトアルブミンと $\beta-$ ラクトグロブリンから構成 されているが, このうち, $\alpha-$ ラトアルブミンはアクチ ニジンの存在とは無関係に, ペプシン単独で完全に消化 された。一方， $\beta$-ラクトグロブリンはペプシンのたんぱ く質分解酵素作用に抵抗性を示し, ほぼそのままの形で 小腸上部に運ばれることが報告されている ${ }^{42,43)}$ 。

キウイフルーツ果汁は, 熱によって変性させたコラー ゲンを pH 3〜 7 の範囲で分解できると報告されてい る ${ }^{44)}$ 。また, 変性コラーゲンであるゼラチンを基質とし たときのアクチニジンの至適 $\mathrm{pH}$ は， 4 前後であること が報告されている17)。Kaur ら ${ }^{13)}$ の研究では, コラーゲ ンやゼラチンの消化に対するアクチニジンの効果は検出 されなかったが, これは, 胃の in vitro 消化モデルにお ける $\mathrm{pH}$ が1.9と低かったことが原因かもしれない。

Kaur ら ${ }^{14)}$ は, アクチニジンの有無が, 胃で消化作用 を受けたたんぱく質が小腸で消化される際に影響するか どうかについても，検証を行った。ヘイワード種キウイ フルーツ抽出物の存在下で胃の in vitro 消化モデルによ る消化を行った後, その消化産物にパンクレアチン（膵 液由来粗酵素）を加え，ヒトの小腸を模した $\mathrm{pH} 8.0$ の環 境下で消化を行った場合と, キウイフルーツ抽出物の非 存在下で同様の反応を行った場合とで, 食物たんぱく質 の消化の状態を比較した。

その結果, 乳清たんぱく質, ゼイン, コラーゲン, グ ルテン, グリアジンにおいて, キウイフルーツ抽出物が 共存する場合の方が, 消化酵素のみの場合よりも消化が 促進された (表 2 )。胃での消化を模したin vitro モデル 単独では, アクチニジンは $\beta$-ラクトグロブリンの消化に 影響を及ぼさなかったが13), 胃と小腸での消化を模した in vitro モデルでは，アクチニジンの存在が消化に影響す ることが示された。 $\beta$-ラクトグロブリンは, あらかじめ ペプシンで処理することで, ほかのたんぱく質分解酵素 に対する感受性がより高まることが知られている ${ }^{45 \sim 47) 。 ~}$ アクチニジンもペプシンと同様に, 胃を模した環境下で $\beta$-ラクトグロブリンに影響を及ぼし，小腸を模した環境 下でのパンクレアチンによる消化を増強させるのかもし れない。

以上の in vitro での研究結果は, キウイフルーツに含 まれるアクチニジンが, ヒトの消化管内での食物たんぱ く質の消化を補助することを強く支持しており, 食物と して摂取したキウイフルーツが，たんぱく質消化を促進 する可能性は非常に高いものと考えられる。

\section{2. in vivo 実験系を用いた研究}

上述した in vitro の実験系に加え, in vivo の実験系で も，キウイフルーツに含まれるアクチニジンの食物たん
ぱく質への消化作用が検証されている。Montoya ら 15$)$ は，成人のモデルとして成長期のラットを用い，食物た んぱく質の胃での消化に対するアクチニジンの効果を確 かめた。実験では，食物たんぱく質にへイワードを加え た飼料と，コントロールとしてホート $16 \mathrm{~A}$ を加えた飼料 の 2 種類を用いた。

たんぱく質の消化速度は胃の内容物排出速度に影響を 与えることが示唆されており ${ }^{48)}$, 飼料中のアクチニジン が胃でのたんぱく質消化に変化をもたらすことで，胃の 内容物排出速度に影響を与える可能性が考えられる。そ こで Montoya ら ${ }^{15)}$ は, キウイフルーツに含まれるアク チニジンが, 食物たんぱく質が胃から排出される速度に 影響を及ぼすかどうかについても併せて検証した。

実験の結果，大豆たんぱく質，牛肉の筋たんぱく質， グルテンで，アクチニジンを含む飼料の方が胃での消化 率が有意に高かった（表 3 ）。胃の内容物排出速度は，ゼ インと牛肉の筋たんぱく質で, アクチニジンを含む飼料 の方が有意に速かった（表 3 )。

胃でのたんぱく質消化速度と胃の内容物排出速度との 相関性を示すエビデンスは，ほとんどない。Montoya ら は，胃でのたんぱく質の消化の度合いと胃に残ったまま の飼料の量との間に負の相関関係を見出した。このこと から, 胃の内容物排出速度はたんぱく質の消化速度にあ る程度依存するものと考えられた。

Montoya ら ${ }^{15)}$ は，ホート $16 \mathrm{~A}$ を含む飼料に精製アクチ ニジンを加えた場合と，へイワードを含む飼料との胃内 容物排出速度に，違いは認められなかったとしている。 ヘイワードとホート $16 \mathrm{~A}$ はアクチニジン含有量が大きく 異なるが，その他の組成は類似している。これらのこと から，アクチニジンを含む飼料で胃の内容物排出速度が 速まるという結果は, 消化管ホルモンのような生理活性 物質を介した胃の運動性の変化によるものという可能性 も否定できないが, アクチニジンによって胃でのたんぱ く質消化率が増大したためであると考えられる。

Montoya ら ${ }^{16)}$ は, 成長期のラットで検証した胃でのた んぱく質消化と胃内容物排出速度に対するアクチニジン の影響を，成長期のブタでも同様に検証した。その結 果, 摂食後 5 時間では, アクチニジンを含む飼料の方が 胃でのたんぱく質消化率が有意に高かった（表 3 ）。摂食 後 5 時間を過ぎると，アクチニジンのたんぱく質消化促 進効果は認められなかった。胃の内容物排出速度はアク チニジンを含む飼料の方が速く, 胃の内容物半減速度は アクチニジンを含む飼料では134〜139分, アクチニジン を含まない飼料では159〜184分であった。

一般的に，胃から小腸まで速く到達できるたんぱく質 
表 3 in vivo でのたんぱく質消化と胃内容物排出速度に対するキウイフルーツ (アクチニジン) の効果

\begin{tabular}{|c|c|c|}
\hline たんぱく質の種類 & $\begin{array}{c}\text { 胃での消化に } \\
\text { 対する効果 }\end{array}$ & $\begin{array}{c}\text { 胃内容物排出速度に } \\
\text { 対する効果 }\end{array}$ \\
\hline 乳清たんぱく質 & - & - \\
\hline ゼイン & - & + \\
\hline 大豆たんぱく質 & + & - \\
\hline 牛肉の筋たんぱく質 & $\begin{array}{l}\text { 成長期のラット：+ } \\
\text { 成長期のブタ：+ }\end{array}$ & $\begin{array}{l}\text { 成長期のラット：+ } \\
\text { 成長期のブタ：+ }\end{array}$ \\
\hline ゼラチン & - & - \\
\hline グルテン & + & - \\
\hline \multicolumn{3}{|c|}{$\begin{array}{l}+ \text { ：アクチニジンを含まない飼料と比較して有意差あり }(p<0.05),- \text { : 有意差なし } \\
\text { 牪肉の筋たんぱく質以外のたんぱく質は, 成長期のラットでの結果。胃での消化に対 } \\
\text { する効果は, 摂食後 } 5 \text { 時間でのたんぱく質分解の度合いで評価した。 } \\
\text { Montoya, C.A., et al. (15) および Montoya, C.A., et al. (16) の結果より作表 }\end{array}$} \\
\hline
\end{tabular}

は, 小腸で消化・吸収され, 生体内でのたんぱく質代謝 にすぐに利用できる15,49)。Montoya ら ${ }^{15)}$ は, 得られた実 験結果から，1時間あたりに胃から小腸へと送られるた んぱく質の量は，実験に用いたいずれの食物たんぱく質 でもアクチニジンを含む飼料の方が多いと推定してい る。このことから, 飼料に含まれるアクチニジンは, 腸 でのアミノ酸吸収をより速める可能性がある。この動物 実験での結果がそのままヒトにも適用できるかどうかは 未だ不明であるが, アクチニジンを豊富に含むキウイフ ルーツは, 胃腸内での消化に障害のある人や, 筋たんぱ く質の合成を高めたい人にとって有益な果物とも考えら れ, 今後の研究成果が期待される。

\section{V. おわりに}

上述の in vitro や in vivo での研究結果から, 食物とし て摂取したキウイフルーツによる消化促進効果が期待さ れる。ニュージーランドではすでに, 消化促進効果を 謳った, キウイフルーツを原料としたサプリメントが市 販されている。キウイフルーツがもつたんぱく質分解促 進作用は, 肉, 乳製品, 穀物, 大豆など様々な食品に含 まれるたんぱく質に対して発揮されるため, 消化酵素の 産生量が低下することで消化機能の低下がみられる高齢 者にとっては有益であろう。また，アスリートなど高た んぱく質食を摂取する人では膨満感や胃の不快感が生じ ることがあると指摘されているが50), キウイフルーツに はそうした症状の軽減効果も期待できる。

風味や鮮やかな色だけでなく, 栄養バランスに優れ, 消化促進効果も期待できる点は, キウイフルーツの魅力 である。いつでも簡単に入手でき, 長期の貯蔵も可能で
あるキウイフルーツは, 健康の維持・増進のために大き な可能性をもつ果物の一つと考えられる。

\section{利益相反}

利益相反に相当する事項はない。

\section{文献}

1) Ferguson, A.R.: 1904-the year that kiwifruit (Actinidia deliciosa) came to New Zealand, N. Z.J. Crop Hortic. Sci., 32, 3-27 (2004)

2) Nishiyama, I.: Fruits of the actinidia genus, Adv. Food Nutr. Res., 52, 293-324 (2007)

3) Hunter, D.C., Skinner, M.A., Ferguson, A.R., et al.: Kiwifruit and health, Bioactive Foods in Promoting Health: Fruits and Vegetables (Watson, R.R., Preedy, V.R., eds.), pp.565-580 (2010) Elsevier, San Diego

4）文部科学省科学技術 - 学術審議会資源調査分科会 : 日 本食品標準成分表2010，pp. 114-115（2010）全国官報販 売協同組合, 東京

5）厚生労働省「日本人の食事摂取基準（2015年版）」策定 検討会：日本人の食事摂取基準（2015年版）, pp. 226229 (2014) 第一出版, 東京

6) Nishiyama, I., Yamashita, Y., Yamanaka, M., et al.: Varietal difference in vitamin $\mathrm{C}$ content in the fruit of kiwifruit and other Actinidia species, J. Agric. Food Chem., 52, 54725475 (2004)

7) Nishiyama, I., Fukuda, T., Oota, T.: Genotypic differences in chlorophyll, lutein, and beta-carotene contents in the fruits of Actinidia species, J. Agric. Food Chem., 53, 64036407 (2005)

8) Hart, D.J., Scott, K.J.: Development and evaluation of an HPLC method for the analysis of carotenoids in foods, and the measurement of the carotenoid content of vegetables and fruits commonly consumed in the UK, Food Chem., 54, 101-111 (1995) 
9) Tee, E.S., Lim, C.L.: Carotenoid composition and content of Malaysian vegetables and fruits by the AOAC and HPLC methods, Food Chem., 41, 309-339 (1991)

10) Rush, E.C., Patel, M., Plank, L.D., et al.: Kiwifruit promotes laxation in the elderly, Asia Pac. J. Clin. Nutr., 11, 164-168 (2002)

11) Chan, A.O.O., Leung, G., Tong, T., et al.: Increasing dietary fiber intake in terms of kiwifruit improves constipation in Chinese patients, World J. Gastroenterol., 13, 4771-4775 (2007)

12) Chang, C.C., Lin, Y.T., Lu, Y.T., et al.: Kiwifruit improves bowel function in patients with irritable bowel syndrome with constipation, Asia Pac. J. Clin. Nutr., 19, 451-457 (2010)

13) Kaur, L., Rutherfurd, S.M., Moughan, P.J., et al.: Actinidin enhances gastric protein digestion as assessed using an in vitro gastric digestion model, J. Agric. Food Chem., 58, 5068-5073 (2010)

14) Kaur, L., Rutherfurd, S.M., Moughan, P.J., et al.: Actinidin enhances protein digestion in the small intestine as assessed using an in vitro digestion model, J. Agric. Food Chem., 58, 5074-5080 (2010)

15) Montoya, C.A., Hindmarsh, J.P., Gonzalez, L., et al.: Dietary actinidin from kiwifruit (Actinidia deliciosa cv. Hayward) increases gastric digestion and the gastric emptying rate of several dietary proteins in growing rats, J. Nutr., 144, 440-446 (2014)

16) Montoya, C.A., Rutherfurd, S.M., Olson, T.D., et al.: Actinidin from kiwifruit (Actinidia deliciosa cv. Hayward) increases the digestion and rate of gastric emptying of meat proteins in the growing pig, Br.J. Nutr., 111, 957-967 (2014)

17) Arcus, A.C.: Proteolytic enzyme of Actinidia chinensis, Biochim. Biophys. Acta, 33, 242-244 (1959)

18) McDowall, M.A.: Anionic proteinase from Actinidia chinensis. Preparation and properties of the crystalline enzyme, Eur.J. Biochem., 14, 214-221 (1970)

19) Carne, A., Moore, C.H.: The amino acid sequence of the tryptic peptides from actinidin, a proteolytic enzyme from the fruit of Actinidia chinensis, Biochem. J., 173, 73-83 (1978)

20) Baker, E.N.: Structure of actinidin: details of the polypeptide chain conformation and active site from an electron density map at $2.8 \AA$ resolution, J. Mol. Biol., 115, 263-277 (1977)

21）西山一朗：精製アクチニジンによる筋原線維タンパク 質分解作用の $\mathrm{pH}$ 依存性, 日本家政学会誌, 52, 10831089 (2001)

22) Boland, M.J., Hardman, M.J.: Kinetic studies on the thiol protease from Actinidia chinensis, FEBS Lett., 27, 282-284 (1972)

23) Boyes, S., Strübi, P., Marsh, H.: Actinidin levels in fruit of Actinidia species and some Actinidia arguta rootstockscion combinations, Lebensm. Wiss. Technol., 30, 379-389 (1997)

24) Sugiyama, S., Ohtsuki, K., Sato, K., et al.: Enzymatic properties, substrate specificities and $\mathrm{pH}$-activity profiles of two kiwifruit proteases, J. Nutr. Sci. Vitaminol., 43, 581-589 (1997)

25) Lewis, D.A., Luh, B.S.: Development and distribution of actinidin in kiwifruit (Actinidia chinensis) and its partial characterization, J. Food Biochem., 12, 109-116 (1988)

26) Préstamo, G.: Actinidin in kiwifruit cultivars, Z. Lebensm. Unters. Forsch., 200, 64-66 (1995)

27）西山一朗, 大田忠親 : キウイフルーツ果汁のアクチニ ジン濃度およびプロテアーゼ活性の品種間差, 日本食品 科学工学会誌, 49, 401-408 (2002)

28） Nieuwenhuizen, N.J., Maddumage, R., Tsang, G.K., et al.: Mapping, complementation, and targets of the cysteine protease actinidin in kiwifruit, Plant Physiol., 158, 376-388 (2012)

29) Funaki, J., Yano, M., Abe, K., et al.: Inhibiting the activity of actinidin by oryzacystatin for the application of fresh kiwifruit to gelatin-based foods, J. Food Biochem., 19, 355-365 (1996)

30) Bachmann, M.R., Farah, Z.: Occurrence of bitter taste in mixtures of milk proteins and kiwi fruit (Actinidia chinensis), Lebensm. Wiss. Technol., 15, 157-158 (1982)

31) Puglisi, I., Petrone, G., Piero, A.R.L.: A kiwi juice aqueous solution as coagulant of bovine milk and its potential in Mozzarella cheese manufacture, Food and Bioproducts Processing, 92, 67-72 (2014)

32) Lawrie, R.A.: The eating quality of meat, Lawrie's Meat Science Sixth Edition, pp. 212-257 (1998) Woodhead Publishing, Cambridge

33）田平洋一：各栄養素の消化・吸収部位と動態, キー ワードでわかる臨床栄養 改訂版（大熊利忠，金谷節子 編), pp. 75-80 (2011) 羊土社, 東京

34）新谷尚弘：Pepsin A，酵素ハンドブック 第 3 版（八 木達彦, 福井俊郎, 一島英治, 鏡山博行, 虎谷哲夫編), p. 668（2008）朝倉書店, 東京

35） Rutherfurd, S.M., Montoya, C.A., Zou, M.L., et al.: Effect of actinidin from kiwifruit (Actinidia deliciosa cv. Hayward) on the digestion of food proteins determined in the growing rat, Food Chem., 129, 1681-1689 (2011)

36) Roubenoff, R.: Sarcopenia and its implications for the elderly, Eur. J. Clin. Nutr., 54, S40-S47 (2000)

37) Dangin, M., Guillet, C., Garcia-Rodenas, C., et al.: The rate of protein digestion affects protein gain differently during aging in humans, J. Physiol., 549, 635-644 (2003)

38）上野川修一, 久恒辰博, 八村敏志 : 経口免疫寛容の分 子生物学, 蛋白質 核酸 酵素, 39, 2090-2101（1994）

39) Untersmayr, E., Jensen-Jarolim, E.: The role of protein digestibility and antacids on food allergy outcomes, $J$. Allergy Clin. Immunol., 121, 1301-1310 (2008)

40) Untersmayr, E., Bakos, N., Schöll, I., et al.: Anti-ulcer drugs promote IgE formation toward dietary antigens in adult patients, FASEB J., 19, 656-658 (2005)

41) Guo, M.R., Fox, P.F., Flynn, A., et al.: Susceptibility of $\beta$-lactoglobulin and sodium caseinate to proteolysis by pepsin and trypsin, J. Dairy Sci., 78, 2336-2344 (1995)

42) Chobert, J.M., Briand, L., Grinberg, V., et al.: Impact of 
esterification on the folding and the susceptibility to peptic proteolysis of $\beta$-lactoglobulin, Biochim. Biophys. Acta, 1248, 170-176 (1995)

43) Kitabatake, N., Kinekawa, Y.: Digestibility of bovine milk whey protein and $\beta$-lactoglobulin in vitro and in vivo, $J$. Agric. Food Chem., 46, 4917-4923 (1998)

44) Sugiyama, S., Hirota, A., Okada, C., et al.: Effect of kiwifruit juice on beef collagen, J. Nutr. Sci. Vitaminol., 51, 27-33 (2005)

45) Roufik, S., Gauthier, S.F., Turgeon, S.L.: Physicochemical characterization and in vitro digestibility of $\beta$-lactoglobulin/ $\beta$-Lg f142-148 complexes, Int. Dairy J., 17, 471-480 (2007)

46) Antila, P., Paakkari, I., Järvinen, A., et al.: Opioid peptides derived from in-vitro proteolysis of bovine whey proteins, Int. Dairy J., 1, 215-229 (1991)

47) Porter, D.H., Swaisgood, H.E., Catignani, G.L.:
Characterization of an immobilized digestive enzyme system for determination of protein digestibility, J. Agric. Food Chem., 32, 334-339 (1984)

48) Hara, H., Nishikawa, H., Kiriyama, S.: Different effects of casein and soyabean protein on gastric emptying of protein and small intestinal transit after spontaneous feeding of diets in rats, Br. J. Nutr., 68, 59-66 (1992)

49) Gaudichon, C., Roos, N., Mahé, S., et al.: Gastric emptying regulates the kinetics of nitrogen absorption from ${ }^{15} \mathrm{~N}$-labeled milk and ${ }^{15} \mathrm{~N}$-labeled yogurt in miniature pigs, J. Nutr., 124, 1970-1977 (1994)

50) Kaur, L., Boland, M.: Influence of kiwifruit on protein digestion, Adv. Food Nutr. Res., 68, 149-167 (2013)

(受付：平成26年 5 月 30 日, 受理 : 平成26年10月31日) 


\title{
Research Trends on the Effect of Kiwifruit in Promoting Digestion and the Role of Actinidin
}

\author{
Ichiro Nishiyama
}

Faculty of Human Health, Komazawa Women's University

\begin{abstract}
Kiwifruit has a long shelf-stability and is readily available at any time of year. Consequently, it is consumed worldwide including Japan. Kiwifruit, a highly nutritious food containing vitamin C and lutein (a carotenoid), is also rich in dietary fiber. Furthermore, it contains the proteolytic enzyme, actinidin. The digestionpromoting action of actinidin has received attention in recent years.

In this article, the enzymatic properties of actinidin and the results of the latest research examining its digestion-promoting effect, in vitro and in vivo, are presented. These recent findings suggest that actinidin enhanced amino acid absorption, by stimulating the digestion of various food-derived proteins in the gastrointestinal tract, and accelerated the expulsion of gastric contents. Therefore, this suggests that kiwifruit has the potential to facilitate digestion. This, in addition to its high nutritional value, makes kiwifruit favorable for the maintenance and improvement of health.
\end{abstract}

Jpn. J. Nutr. Diet., 72 (6) 292 301 (2014)

Key words: kiwifruit, actinidin, promotion of digestion, proteolytic enzyme, health promotion 